\title{
Heart-type fatty acid binding protein (H-FABP) in patients in an emergency department setting, suspected of acute coronary syndrome: Optimal cut- off point, diagnostic value and future opportunities in primary care
}

Citation for published version (APA):

Willemsen, R. T. A., van Severen, E., Vandervoort, P. M., Grieten, L., Buntinx, F., Glatz, J. F. C., \& Dinant, G. J. (2015). Heart-type fatty acid binding protein (H-FABP) in patients in an emergency department setting, suspected of acute coronary syndrome: Optimal cut-off point, diagnostic value and future opportunities in primary care. European Journal of General Practice, 21(3), 156-163. https://doi.org/10.3109/13814788.2015.1013934

Document status and date:

Published: 01/01/2015

DOI:

10.3109/13814788.2015.1013934

Document Version:

Publisher's PDF, also known as Version of record

\section{Document license:}

Taverne

Please check the document version of this publication:

- A submitted manuscript is the version of the article upon submission and before peer-review. There can be important differences between the submitted version and the official published version of record. People interested in the research are advised to contact the author for the final version of the publication, or visit the DOI to the publisher's website.

- The final author version and the galley proof are versions of the publication after peer review.

- The final published version features the final layout of the paper including the volume, issue and page numbers.

Link to publication

\footnotetext{
General rights rights.

- You may freely distribute the URL identifying the publication in the public portal. please follow below link for the End User Agreement:

www.umlib.nl/taverne-license

Take down policy

If you believe that this document breaches copyright please contact us at:

repository@maastrichtuniversity.nl

providing details and we will investigate your claim.
}

Copyright and moral rights for the publications made accessible in the public portal are retained by the authors and/or other copyright owners and it is a condition of accessing publications that users recognise and abide by the legal requirements associated with these

- Users may download and print one copy of any publication from the public portal for the purpose of private study or research.

- You may not further distribute the material or use it for any profit-making activity or commercial gain

If the publication is distributed under the terms of Article $25 \mathrm{fa}$ of the Dutch Copyright Act, indicated by the "Taverne" license above,

Download date: 26 Apr. 2023 


\section{Heart-type fatty acid binding protein (H-FABP) in patients in an emergency department setting, suspected of acute coronary syndrome: Optimal cut-off point, diagnostic value and future opportunities in primary care}

Robert TA Willemsen, Evie van Severen, Pieter M Vandervoort, Lars Grieten, Frank Buntinx, Jan FC Glatz \& Geert Jan Dinant

To cite this article: Robert TA Willemsen, Evie van Severen, Pieter M Vandervoort, Lars Grieten, Frank Buntinx, Jan FC Glatz \& Geert Jan Dinant (2015) Heart-type fatty acid binding protein (HFABP) in patients in an emergency department setting, suspected of acute coronary syndrome: Optimal cut-off point, diagnostic value and future opportunities in primary care, European Journal of General Practice, 21:3, 156-163, DOI: 10.3109/13814788.2015.1013934

To link to this article: https://doi.org/10.3109/13814788.2015.1013934

曲 Published online: 09 Mar 2015.

Џلll Article views: 1197

View Crossmark data $\longleftarrow$

$\bigodot_{\text {cosssuatk }}$ View Crossmark data 5
Submit your article to this journal $\sqsubset$

Q View related articles 5

Citing articles: 3 View citing articles 4 


\title{
Heart-type fatty acid binding protein (H-FABP) in patients in an emergency department setting, suspected of acute coronary syndrome: Optimal cut-off point, diagnostic value and future opportunities in primary care*
}

\author{
Robert TA Willemsen ${ }^{1}$, Evie van Severen ${ }^{2}$, Pieter M Vandervoort ${ }^{3}$, Lars Grieten ${ }^{3}$, Frank Buntinx ${ }^{1,2}$, \\ Jan FC Glatz ${ }^{4}$ \& Geert Jan Dinant ${ }^{1}$ \\ ${ }^{1}$ Department of Family Medicine, Maastricht University, Maastricht, the Netherlands, ${ }^{2}$ Department of General Practice, Catholic \\ University Leuven, Leuven, Belgium, ${ }^{3}$ Department of Cardiology, Hospital Oost-Limburg, Genk, Belgium, ${ }^{4}$ Department of Genetics \\ \& Cell Biology, Maastricht University, Maastricht, the Netherlands
}

KEY MESSAGE:

- In patients with chest pain, heart-type fatty acid binding protein (H-FABP) and high sensitivity troponin T (hs-cTnT) have a similar diagnostic potency.

- The optimal cut-off value for H-FABP is $4 \mathrm{ng} / \mathrm{ml}$.

- The diagnostic value of combining H-FABP measurement with clinical findings should be studied in primary care.

\section{ABSTRACT}

Background: Most patients presenting chest complaints in primary care are referred to secondary care facilities, whereas only a few are diagnosed with acute coronary syndrome (ACS).

Objective: The aim is to determine the optimal cut-off value for a point-of-care heart-type fatty acid binding protein (H-FABP) test in patients presenting to the emergency department and to evaluate a possible future role of H-FABP in safely ruling out ACS in primary care.

Methods: Serial plasma H-FABP (index test) and high sensitivity troponin T (hs-cTnT) (reference test) were determined in patients with any new-onset chest complaint. In a receiver operating characteristic (ROC) curve, the optimal cut-off value of H-FABP for ACS was determined. Predictive values of H-FABP for ACS were calculated.

Results: For 202 consecutive patients (prevalence ACS 59\%), the ROC curve based on the results of the first H-FABP was equal to the ROC curve of hs-cTnT (AUC 0.79 versus 0.80 ). Using a cut-off value of $4.0 \mathrm{ng} / \mathrm{ml}$ for H-FABP, sensitivity for ACS of the H-FABP (hs-cTnT) tests was $73.9 \%$ (70.6\%). Negative predictive value (NPV) of H-FABP for ACS in a population representative for primary care (incidence of ACS 22\%) thus could reach $90.8 \%$.

Conclusion: In patients presenting chest pain, plasma H-FABP reaches the highest diagnostic value when a cut-off value of $4 \mathrm{ng} / \mathrm{ml}$ is used. Diagnostic values of an algorithm combining point-of-care H-FABP measurement and a score of signs and symptoms should be studied in primary care, to learn if such an algorithm could safely reduce referral rate by GPs.

Keywords: Acute coronary syndrome, point-of-care systems, heart-type fatty acid binding protein, early diagnosis, referral

INTRODUCTION

Background

Patients with symptoms possibly due to acute coronary syndrome (ACS) frequently contact their general practitioner (GP) first. In case of suspected ACS, patients will be urgently referred to a secondary care facility since early treatment of ACS markedly increases survival and quality of life $(1,2)$. In primary

\footnotetext{
*Oral presentation at the annual research conference of the European Primary Care Cardiovascular Society (EPCCCS) in London, September 2013.

Correspondence: Robert T. A. Willemsen, Department of Family Medicine Maastricht University, PO Box 616, 6200 MD Maastricht, the Netherlands. Tel: + 31 (0)433882302. Email: robert.willemsen@maastrichtuniversity.nl
}

This article was originally published with errors. This version has been corrected. Please see Erratum (http://dx.doi.org/10.3109/13814788.2015.1040688). 
care, however, differential diagnosis of chest complaints is broad, and ACS is present only in a minority of patients (3). In addition, signs or symptoms decisively distinguishing ACS (with a low prevalence) from high prevalent diagnoses with an advantageous course have not been described earlier $(4,5)$. Furthermore, an electrocardiogram (ECG) reveals no signs of ischaemia in a significant number of patients (6). Therefore, diagnostic means accessible for GPs lack potency to safely rule out ACS and a low threshold for referring patients with possible ACS is maintained. In literature, incidence of ACS among patients presenting symptoms suspected for ACS, is at most $22 \%$ and incidence of acute myocardial infarction (AMI) $17 \%(7,8)$. In a Dutch cohort of such patients, $27 \%$ of patients were not referred, in $8 \%$ of whom ACS was diagnosed at a later stage, leading to a false negativity rate of $2 \%$. A total of $73 \%$ of patients were referred, $75 \%$ of whom were not diagnosed with ACS (false positivity rate or 'unnecessary referral rate' $54.8 \%)(7,9)$. For a safer and more costeffective referral policy by GPs, new diagnostic means should become available.

Serial measurement of plasma high sensitivity cardiac specific troponin (hs-cTn), the cornerstone in diagnosing as well as ruling out AMI, is impossible to perform in primary care $(10,11)$. Furthermore, current point-of-care troponin tests are less accurate due to detection limits higher than the widely used cut-off values for a positive test, usually set at the 99th percentile of a healthy population (12). Heart-type fatty acid binding protein (H-FABP) is a small sized protein (molecular mass $15 \mathrm{kD}$ ) (13). Therefore, in case of AMI, elevation of plasma H-FABP can be detected within the first one-two hours after onset of complaints (14-16). Several studies have described an added value of H-FABP when measured besides troponin in an emergency room setting in an early phase $(17,18)$. As a solitary rule-out test at admission, high sensitivity cardiac specific troponin T (hs-cTnT) outperforms H-FABP slightly but H-FABP tested in addition to hs-TnT leads to an increase in sensitivity compared to hs-TnT alone (19). The value of H-FABP as a solitary marker in a primary care setting with a typical low prevalence of ACS has been studied once using a point-of-care H-FABP test. Prevalence of ACS was $22 \%$ in this study (7). Safe implementation of this test in daily care was opposed by excessive false negative results. This was possibly caused by the relatively high cut-off value for H-FABP $(7 \mathrm{ng} / \mathrm{ml})$ of the point-of-care test and a high number of early presenters (presenting within three hours after onset of symptoms) included in this study. In daily general practice, however, a point-of-care test facilitating early rule-out of ACS and reducing unnecessary referral to secondary care facilities would improve the interface between primary and secondary care. It would add to an evidence-based approach of unselected and early presented problems that GPs are faced with and it would increase efficient use of diagnostic facilities in primary care. Thus, several main goals, as formulated by the European General Practice Research Network in the research agenda for general practice/family medicine and primary health care in Europe (http://www. egprn.org) are met.

\section{Objectives}

The main objectives of this study are twofold. First, the intention to determine the optimal cut-off value for a point-of-care H-FABP test. Second, to evaluate H-FABP as a potential marker for early triage of patients presenting complaints possibly due to ACS in primary care. Therefore, in an emergency department setting, plasma $\mathrm{H}$-FABP and high sensitivity troponin T (hs-cTnT) levels were compared in an early phase after onset of chest complaints. This study is part of a larger project focusing on point-of-care H-FABP testing in suspected ACS in primary care.

\section{METHODS}

\section{Study design}

A delayed type cross-sectional diagnostic study was performed in the emergency department of Ziekenhuis Oost-Limburg (ZOL), a large academic hospital in Genk, Belgium.

\section{Patient selection}

Patients consecutively presenting with cardiac symptoms (presence of acute pain, discomfort or pressure in either chest, epigastric, neck, jaw or arm) or atypical symptoms suspected of cardiac origin (fatigue, nausea, vomiting, diaphoresis, faintness and back pain, without apparent non-cardiac source like a trauma) after triage by an emergency department physician were included. Excluded were patients from whom no informed consent could be obtained and patients with symptoms lasting more than $24 \mathrm{~h}$ (H-FABP levels return to baseline 24-36 $\mathrm{h}$ after onset of myocardial ischaemia) (13). Patients visited the emergency department on their initiative or they were brought in by an emergency service after referral by a GP or after contacting the emergency service themselves. All patients received routine care considering rule in and rule out of ACS and subsequent treatment. Treating physicians were blind to H-FABP results. A flowchart summarizing patient numbers and the process of inclusion is presented in Figure 1.

\section{Informed consent}

Obtaining patients' written informed consent in an acute life-threatening situation was considered inconvenient. 


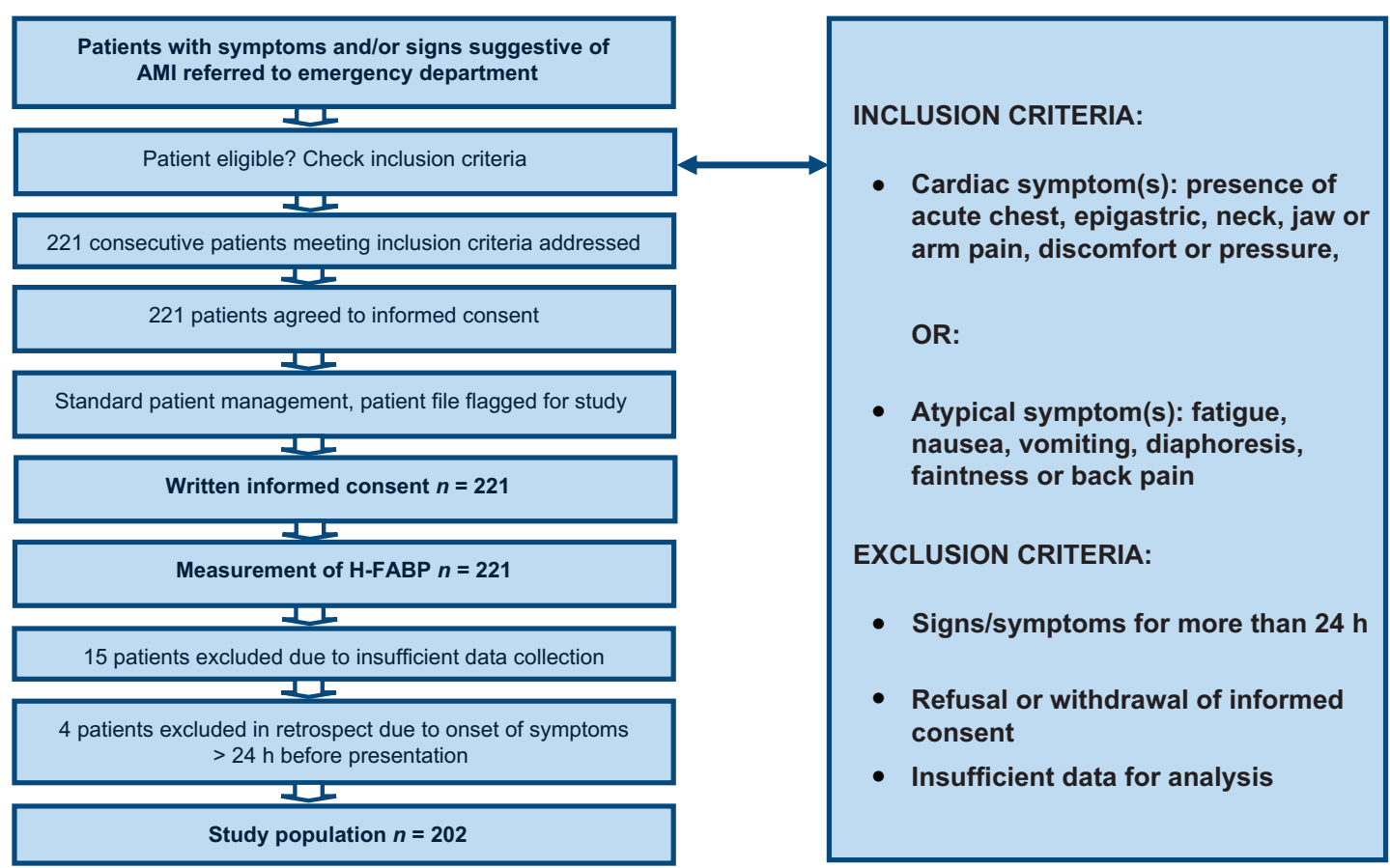

Figure 1. Study flow chart as executed in the emergency service of the hospital of Genk, Belgium. AMI, acute myocardial infarction; H-FABP, hearttype fatty acid binding protein.

Furthermore, all medical acts were part of usual care, including blood sampling, except for the additional determination of H-FABP. Patients were, therefore, asked for written informed consent at a later stage. They could decide to withdraw their consent then or at any time after. Only H-FABP results and clinical data of patients who returned a written informed consent were included in the study. The study protocol was in agreement with the WMA Declaration of Helsinki for Ethical Principles for Medical Research Involving Human Subjects and was approved by the Ethical Review Board of ZOL that specifically agreed on the solution for the consent procedure as described above.

\section{Measurements}

Presence of the inclusion criteria, symptoms, ECG-findings, time of onset of symptoms, time of drawing the initial blood sample and all laboratory test results were documented. The initial blood samples to measure $\mathrm{H}$-FABP and hs-cTnT were collected by the ambulance staff immediately upon arrival at the patient's site or arrival in our hospital. Routinely, in all venous blood samples - at presentation and any time later during the evaluation at the emergency department-plasma creatinine and hs-cTnT (using Elecsys Cobas fifth-generation hs-cTnT assay by Roche Diagnostics) were measured. Estimated glomerular filtration rate (eGFR) was measured in order to determine the influence of renal clearance on H-FABP and hs-cTn test results. Additionally, a quantitative H-FABP measurement was performed using an H-FABP assay developed by FABPulous BV (limit of detection: $0.5 \mathrm{ng} / \mathrm{ml}$; 99th percentile in a healthy reference population: $5.3 \mathrm{ng} / \mathrm{ml}$ ) (20).

\section{Outcomes}

To allow for a final (gold standard) diagnosis, an ECG was recorded and serial venous blood samples to determine hs-cTnT-used as the reference standard-were analysed. Final diagnoses were established by propounding all data available after an in hospital follow-up of at least 12 $h$ to an expert panel of one independent GP and one independent cardiologist. The expert panel had access to all clinical data including, if performed, the results of coronary angiography. In cases of disagreement, two extra cardiologists and GPs were consulted to determine the final diagnosis unanimously. The expert panel based all decisions on definitions of final diagnoses that were unambiguous and determined beforehand according to current guidelines $(10,11,21-24)$. The expert panel thus utilized the following possible diagnoses: acute myocardial infarction (AMI) with or without ST elevations on ECG (STEMI or nSTEMI), unstable angina (UA), stable angina, no coronary disorders. See Table 1 for complete definitions.

\section{(Statistical) analysis}

Receiver operating characteristic (ROC) curves have been used to find the mathematical optimal cut-off point of the venous H-FABP-test for ACS as well as to compare 
Table 1. Outcome definitions as used by the expert panel.

\begin{tabular}{|c|c|}
\hline Diagnosis & Definition as used by expert panel \\
\hline AMI & $\begin{array}{l}\text { Clinical presence of ACS with ECG-changes, hs-cTn results or results of imaging techniques supporting myocardial } \\
\text { infarction. Exact cut-off values of hs-cTn were defined using the } 99 \text { th percentile of the upper reference limit in a } \\
\text { normal reference population, as is widely accepted }(10,11) \text {. In all cases of AMI, distinction was made between STEMI } \\
\text { and non-STEMI. }\end{array}$ \\
\hline nSTEMI & $\begin{array}{l}\text { A situation of complaints indicative for ACS combined with at least one measurement of hs-cTn above the } 99 \text { th } \\
\text { percentile and thereby a change between two measurements of at least } 20 \% \text {, without ST elevations on ECG } \\
\text { recordings (21). }\end{array}$ \\
\hline STEMI & Complaints indicative for ACS combined with ST elevations on ECG recordings (23). \\
\hline Unstable angina & $\begin{array}{l}\text { Clinical presence of ACS based on typical and recently developed or altered symptoms of myocardial ischemia without } \\
\text { changes in ECG or hs-cTn indicative for AMI (21). }\end{array}$ \\
\hline Stable angina & $\begin{array}{l}\text { Angina pectoris occurring in a patient in predictable situations for months, without a recent change in severity or } \\
\text { amount of exertion that is needed for angina pectoris to occur (22). }\end{array}$ \\
\hline No coronary disorder & No coronary disorder was diagnosed when AMI, stable angina and unstable angina were excluded. \\
\hline
\end{tabular}

AMI, acute myocardial infarction; ACS, acute coronary syndrome; ECG, electrocardiogram; hs-cTn, high sensitivity cardiac specific troponin; STEMI, ST elevated myocardial infarction; nSTEMI, non-ST elevated myocardial infarction.

$\mathrm{H}$-FABP to the reference test, hs-cTnT. We used exact tests for comparisons between two areas under the curve (AUC) (25). Sensitivity, specificity, positive and negative likelihood ratios (PLR and NLR) for AMI and ACS of $\mathrm{H}$-FABP (cut-off value between positive and negative: greater or equal to $4 \mathrm{ng} / \mathrm{ml}$ ) and hs-cTnT (cut-off value between positive and negative: above $14 \mathrm{pg} / \mathrm{ml}$ ) were determined, using outcomes of the expert panel as undisputed diagnoses. Potential negative and positive predictive value (NPV and PPV) in a primary care setting were calculated using Bayes' theorem. SPSS statistics version 21 and MedCalc were used for the statistical analyses. Before the start of the study, a power calculation revealed that $100 \mathrm{AMI}$ patients were required to compare properly the performance of the plasma biomarkers.

\section{RESULTS}

Agreement to the study consent was given by 221 consecutive patients. Four patients appeared to have complaints for more than $24 \mathrm{~h}$. For 15 patients, data collection was insufficient. Therefore, data of 202 patients meeting the inclusion criteria was analysed. Patient characteristics are displayed in Table 2. Duration of the complaints ranged between $15 \mathrm{~min}$ and $23.3 \mathrm{~h}$. Median duration of complaints was $3 \mathrm{~h}$ and $54 \mathrm{~min}$. Of the 202 admitted patients, 119 (59\%) were diagnosed with ACS among whom 111 (55\% of the total population) had an AMI. A total of 157 patients were males, 93 (59\%) of whom had an AMI. Of 45 female patients, 18 (40\%) had an AMI. Median age was 62 years (range 26-93 years) and ages of AMI and non-AMI patients overlapped. The duration of the complaints at first contact was $0-3,3-6,6-12$, and 12-24 $\mathrm{h}$ in $82,40,56$, and 24 patients, respectively. There was no relation between duration of the complaints and AMI risk ( $P=0.11$; Mann-Whitney). In 193 $(96 \%)$ patients, the eGFR was $>30$.
ROC curves based on the results of the first H-FABP and hs-cTnT tests, using ACS as outcome measure, were similar with an area under the curve (AUC) of $0.80(95 \%$ $\mathrm{Cl}: 0.735-0.856)$ for hs-cTnT and 0.79 (95\% Cl: 0.7280.851 ) for H-FABP (Figure 2). The optimal cut-point for $\mathrm{H}-\mathrm{FABP}$, based on inspection of the curve, was at $4.0 \mathrm{ng} /$ $\mathrm{ml}$, resulting in a sensitivity for ACS of $74.8 \%$ and a specificity of $71.1 \%$. Additionally, in Table 3, sensitivity and specificity of H-FABP for ACS at adjacent cut-off values are shown.

Sensitivity of H-FABP is strongly related to time between sample taking and the first complaints. Sensitivity for AMI was $63,88,96,83 \%$ for patients presenting $0-3,3-6,6-12,12-24 \mathrm{~h}$ after onset of symptoms (Table 4). During the first six hours after onset of complaints, sensitivity of H-FABP tended to be higher than that of hs-cTnT, without reaching statistical significance. However, within the first three hours after onset of complaints, sensitivity of H-FABP is lower than sensitivity of

Table 2. Patient characteristics.

\begin{tabular}{lrrr}
\hline & All & AMI (\%) & No AMI (\%) \\
\hline $\begin{array}{l}\text { Number } \\
\text { Gender }\end{array}$ & 202 & $111(55)$ & $91(45)$ \\
$\quad$ Male & 157 & $93(59)$ & $64(41)$ \\
$\quad$ Female & 45 & $18(40)$ & $27(60)$ \\
Age group & & & \\
$\quad>65$ years & 84 & $43(51)$ & $41(49)$ \\
$\quad$ <5 years & 118 & $68(58)$ & $50(43)$ \\
Duration complaints at presentation & & & \\
$\quad 0-3$ h & 82 & $46(56)$ & $36(44)$ \\
$\quad 3-6$ h & 40 & $23(58)$ & $17(43)$ \\
6-12 h & 56 & $29(52)$ & $27(48)$ \\
$\quad 12-24$ h & 24 & $13(54)$ & $11(46)$ \\
eGFR & & & \\
$\quad \geq 30$ & 193 & $108(56)$ & $85(44)$ \\
$<30$ & 9 & $3(33)$ & $6(67)$ \\
\hline
\end{tabular}

AMI, acute myocardial infarction; eGFR, estimated glomerular filtration rate (using modification of diet in renal disease (MDRD)-formula. 


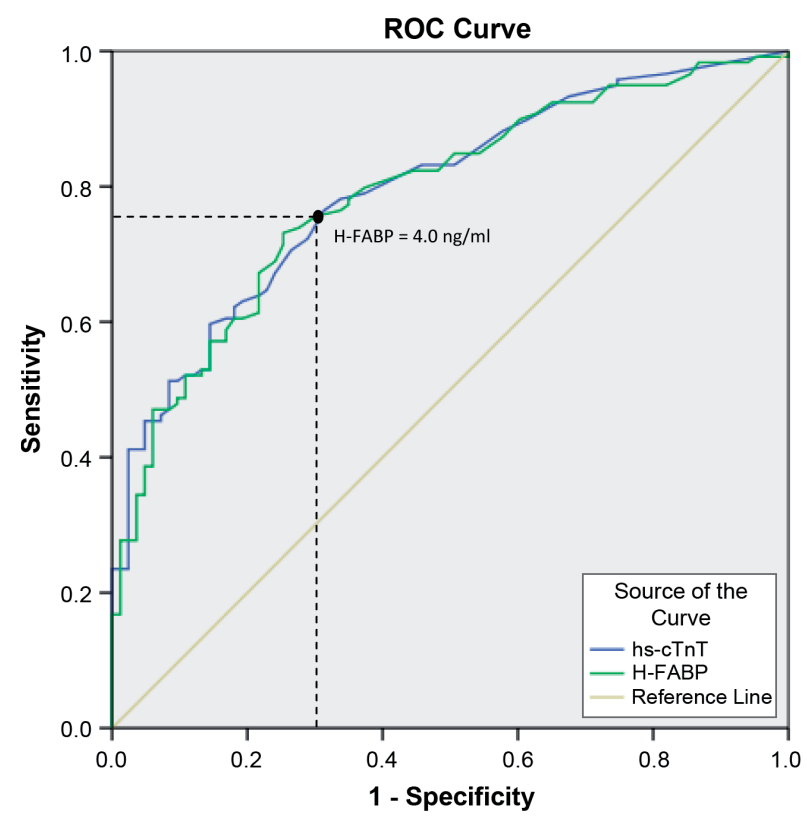

Figure 2. Receiver operating characteristic (ROC) curve of high sensitivity troponin and $\mathrm{H}-\mathrm{FABP}$, optimal cut-off point for $\mathrm{H}$-FABP using ACS as outcome. ACS, acute coronary syndrome; H-FABP, heart-type fatty acid binding protein; hs-cTnT high sensitivity cardiac specific troponin T; ROC curve, receiver operating characteristic curve.

$\mathrm{H}-\mathrm{FABP}$ at a time interval of 3-24 h after onset of complaints. Sensitivity for ACS (UA and AMI) is lower than sensitivity for AMI only (Table 5).

The overall sensitivity and specificity of $\mathrm{H}$-FABP for AMI at presentation using a cut-off value of $4 \mathrm{ng} / \mathrm{ml}$ were $77.5 \%$ and $71.4 \%$ respectively. In a population of patients presenting chest complaints representative for primary care, with an incidence of AMI of $17 \%$, NPV of H-FABP using a cut-off between positive and negative of $4 \mathrm{ng} / \mathrm{ml}$ would reach $93.9 \%$ for all patients and $97.1 \%$ for patients presenting complaints with a duration of at least three hours. For ACS, an overall sensitivity of $73.9 \%$ and a specificity of $71 \%$ was found. With an incidence of ACS in primary care among patients presenting chest complaints of $22 \%$, NPV would reach $90.8 \%$ (Table 6). If only data of patients presenting complaints with a duration of more than three hours are regarded, NPV would amount 94.8\%. Referral is made to Table 3 for NPVs of H-FABP at other cut-off values. Furthermore, negative and positive
Table 3. Sensitivity and specificity of H-FABP for ACS at different cut-off values between positive and negative. Sensitivity and specificity of $\mathrm{H}$-FABP for ACS at different cut-off values are given for all patients presenting complaints with a duration of $0-24 \mathrm{~h}$ and for all patients presenting complaints with a duration of $3-24 \mathrm{~h}$ at presentation. NPV is estimated for a population representative for primary care (incidence of ACS $=22 \%$ ). Sensitivity, specificity and NPV for hs-cTnT with a cut-off of $14 \mathrm{pg} / \mathrm{ml}$ are given for comparison.

\begin{tabular}{|c|c|c|c|c|c|c|}
\hline \multirow{2}{*}{$\begin{array}{l}\text { Cut-off } \\
\text { value }\end{array}$} & \multicolumn{3}{|c|}{$\begin{array}{c}\text { Interval onset } \\
\text { complaints - presentation } \\
0-24 \mathrm{~h}\end{array}$} & \multicolumn{3}{|c|}{$\begin{array}{l}\text { Interval onset } \\
\text { complaints - presentation } \\
\text { (h) } 3-24(\mathrm{ng} / \mathrm{ml})\end{array}$} \\
\hline & Specificity & Sensitivity & NPV & Specificity & Sensitivity & NPV \\
\hline 3.0 & 43.5 & 85.7 & 91.5 & 45.7 & 94.2 & 96.5 \\
\hline 3.5 & 60.9 & 79.0 & 91.1 & 65.2 & 88.4 & 95.2 \\
\hline 4.0 & 71.7 & 73.9 & 90.7 & 73.9 & 85.5 & 95.8 \\
\hline 4.5 & 78.3 & 66.4 & 89.2 & 82.6 & 84.1 & 94.9 \\
\hline 5.0 & 78.3 & 58.8 & 87.1 & 82.6 & 79.7 & 93.5 \\
\hline hs-cTnT & 73.9 & 70.6 & 89.9 & 67.4 & 88.4 & 95.4 \\
\hline
\end{tabular}

ACS, acute coronary syndrome; H-FABP, heart-type fatty acid binding protein; hs-cTnT, high sensitivity cardiac specific troponin T; NPV, negative predictive value.

likelihood ratios as well as odds ratios - all independent of the incidence of ACS-are given in Table 6.

If $\mathrm{H}$-FABP was used as a stand-alone test at presentation, in this population of 202 patients among whom 119 patients were diagnosed with ACS, 31 patients (25 AMI, 6 UA) would test false negative (i.e., H-FABP $<4$ $\mathrm{ng} / \mathrm{ml}$ at presentation in an eventual case of ACS). Using only hs-cTnT at presentation, 35 patients would be missed ( $30 \mathrm{AMI}, 5 \mathrm{UA}$ ). Among 24 false positive cases (i.e., H-FABP at or above $4 \mathrm{ng} / \mathrm{ml}$ in eventually ACS negative patients as based on serial hs-cTnT measurements and clinical judgment), 15 patients were diagnosed with either a non-cardiac mild disease or with stable angina, whereas 9 cases related to moderate to severe alternative cardiac diagnoses needing acute treatment.

$\mathrm{H}-\mathrm{FABP}$ and hs-cTnT values were compared in patients with an eGFR at or above $30 \mathrm{ml} / \mathrm{min}$ versus below $30 \mathrm{ml} /$ min according to their ROC curves and AUC. There was no significant difference between both markers in both subgroups and for each marker the 95\% confidence intervals overlapped with both renal function groups. However, only 9 patients with an eGFR below $30 \mathrm{ml} / \mathrm{min}$ were included.

Table 4. Sensitivity and specificity of hs-cTnT and H-FABP. Sensitivity and specificity of hs-cTnT (cut-off $14 \mathrm{pg} / \mathrm{mL}$ ) and H-FABP (cut-off $4 \mathrm{ng} / \mathrm{mL}$ ) for $\mathrm{AMI}$ at different time intervals after onset of complaints.

\begin{tabular}{|c|c|c|c|c|c|c|c|c|c|c|}
\hline \multirow{2}{*}{$\begin{array}{l}\text { Interval onset } \\
\text { complaints- } \\
\text { presentation (h) }\end{array}$} & \multicolumn{2}{|c|}{$0-3$} & \multicolumn{2}{|c|}{$3-6$} & \multicolumn{2}{|c|}{$6-12$} & \multicolumn{2}{|c|}{$12-24$} & \multicolumn{2}{|c|}{$0-24$} \\
\hline & Sensitivity & Specificity & Sensitivity & Specificity & Sensitivity & Specificity & Sensitivity & Specificity & Sensitivity & Specificity \\
\hline hs-cTnT & 54.9 & 75.7 & 83.3 & 56.3 & 91.7 & 77.8 & 91.7 & 63.3 & 73.0 & 71.4 \\
\hline H-FABP & 62.7 & 70.3 & 87.5 & 56.3 & 95.8 & 81.5 & 83.3 & 72.7 & 77.5 & 71.4 \\
\hline$n$ & 51 & 37 & 24 & 16 & 24 & 27 & 12 & 11 & 111 & 91 \\
\hline
\end{tabular}

H-FABP, heart-type fatty acid binding protein; hs-cTnT, high sensitivity cardiac specific troponin T. 


\section{DISCUSSION}

Main findings

The main objectives of this study were to determine the optimal cut-off point of H-FABP and to assess the possible diagnostic potency of plasma H-FABP in patients presenting with chest pain to the GP. The cut-off value for ACS of H-FABP, where sensitivity and specificity reached optimal values, is $4.0 \mathrm{ng} / \mathrm{ml}$. Using this cut-off value for $\mathrm{H}-\mathrm{FABP}$, sensitivity for AMI of the H-FABP (hs-cTnT) tests was $77.5 \%(73.0 \%)$ for all patients at presentation and the sensitivity for ACS was $73.9 \%$ (70.6\%). Based on the results of this study, H-FABP with a cut-off value of 4.0 $\mathrm{ng} / \mathrm{ml}$ could reach an overall NPV for AMI of $93.9 \%$ and for ACS of $90.8 \%$ in an unselected primary care population (estimation based on a prevalence of ACS of $22 \%$ ).

\section{Strengths and limitations}

The strength of this study is its performance in a population of consecutive patients presenting to an emergency setting covering the broad spectrum of referred and non-referred patients, complying with usual care for chest pain bridging primary and secondary care. The outcome measurement complied with recent evidencebased guidelines (11). Besides, with our emergency department based data in a high prevalence setting of ACS, estimations for an NPV in an unselected primary care setting with a lower prevalence could be made. These estimations are limited by the fact that data was not gathered in a true primary care population, where sensitivity and specificity could differ slightly, as it is known that these parameters are influenced by different characteristics of a given population (26). Thus, further research in primary care has to be carried out to evaluate the actual role of H-FABP in assessing patients who present complaints possibly due to ACS. All the more since in this study laboratory testing was used, whereas pointof-care testing in the field could be susceptible to more user error.

Compared to recent literature, a higher incidence of AMI was found in these patients of $55 \%$. This is probably due to the presence of an emergency doctor that performs triage of patients before consultation by a cardiologist if necessary. Furthermore, using hs-cTnT combined with criteria meeting contemporary international guidelines, incidence of nSTEMI rises, while incidence of UA falls (only $4 \%$ in this population), as is described in current literature (27).

\section{Interpretation, implications for future research}

$\mathrm{H}-\mathrm{FABP}$ as a stand-alone test seems unable to rule in and out ACS, especially in early presenters $(<3 \mathrm{~h})$ and in case of UA. However, the estimated NPV of $90.8 \%$ in a primary care population could be further improved 
Table 6. Predictive values and likelihood ratios. PPV and NPV of hs-cTnT (cut-off $14 \mathrm{pg} / \mathrm{ml}$ ) and H-FABP (cut-off $4 \mathrm{ng} / \mathrm{ml}$ ) for $\mathrm{AMI}$ and ACS at time intervals of $0-24 \mathrm{~h}$ and 3-24 h after onset of complaints in a primary care setting with an incidence of AMI of $17 \%$ and ACS of $22 \%$. PLR, NLR and OR of hs-cTnT (cut-off $14 \mathrm{pg} / \mathrm{ml}$ ) and H-FABP (cut-off $4 \mathrm{ng} / \mathrm{ml}$ ) for AMI and ACS at time intervals of $0-24 \mathrm{~h}$ and $3-24 \mathrm{~h}$ after onset of complaints.

\begin{tabular}{lcccccccccccc}
\hline & \multicolumn{2}{c}{$\mathrm{PPV}$} & \multicolumn{2}{c}{ NPV } & \multicolumn{2}{c}{$\mathrm{PLR}$} & \multicolumn{2}{c}{ NLR } & \multicolumn{2}{c}{ OR } \\
\hline $\begin{array}{l}\text { Interval onset complaints-presentation (h) } \\
\text { hs-CTnT }\end{array}$ & $0-24$ & $3-24$ & $0-24$ & $3-24$ & $0-24$ & $3-24$ & $0-24$ & $3-24$ & $0-24$ & $3-24$ \\
AMI & & & & & & & & & & \\
ACS & 34.3 & 39.5 & 92.8 & 97.3 & 2.55 & 2.94 & 0.38 & 0.13 & 6.75 & 22.0 \\
H-FABP & 42.9 & 47.6 & 89.9 & 94.8 & 2.66 & 3.22 & 0.40 & 0.16 & 6.65 & 20.2 \\
AMI & & & & & & & & & & \\
ACS & 35.7 & 40.1 & 93.9 & 97.1 & 2.71 & 3.27 & 0.32 & 0.15 & 8.60 & 22.1 \\
& 42.9 & 48.6 & 90.8 & 94.8 & 2.67 & 3.36 & 0.36 & 0.20 & 7.41 & 17.2 \\
\hline
\end{tabular}

ACS, acute coronary syndrome; AMI, acute myocardial infarction; H-FABP, heart-type fatty acid binding protein; hs-cTnT, high sensitivity cardiac specific troponin T; NLR, negative likelihood ratio; NPV, negative predictive value; OR, odds ratio; PLR, positive likelihood ratio; PPV, positive predictive value.

when signs and symptoms are added to point-of-care H-FABP measurement in a clinical decision rule (CDR). False positivity of H-FABP alone would be $29 \%$ for ACS, whereas currently $54.8 \%$ of patients presenting chest complaints to their GP are referred without an underlying ACS. Actual effect on referral decisions of a CDR combining signs, symptoms and point-of-care H-FABP testing in primary care merits further study. We, therefore, intend to test the incremental diagnostic value of a recently launched point-of-care H-FABP test with a cutoff value of $4.0 \mathrm{ng} / \mathrm{ml}$ combined with signs and symptoms in primary care (28).

\section{Conclusion}

In patients presenting chest pain at an early stage, H-FABP and hs-CTnT have the similar diagnostic potency. The optimal cut-off value for H-FABP is $4 \mathrm{ng} / \mathrm{ml}$. Possibly, $\mathrm{H}$-FABP could be of value in reducing referrals by GPs of eventually ACS negative patients and in reducing missed cases of ACS in primary care. Thus, in future studies performed by GPs, the diagnostic value of a CDR, combining signs, symptoms and point-of-care H-FABP testing-using $4.0 \mathrm{ng} / \mathrm{ml}$ as a cut-off value-in a true primary care population should be studied.

\section{ACKNOWLEDGEMENTS}

All authors should like to thank participating patients, as well as all emergency personnel executing our research protocol at hospital ZOL, Genk, Belgium.

\section{FUNDING}

The study is funded by means of an unrestricted grant by FABPulous BV, the company that develops point-ofcare H-FABP-tests. FABPulous BV agreed not to interfere with data collection, data management and analysis of data. Publication of possible unfavourable outcome of our study was guaranteed.

Declaration of interest: JG is chief scientific officer (CSO) at FABPulous BV. The remaining authors report no conflicts of interest. The authors alone are responsible for the content and writing of the paper.

\section{REFERENCES}

1. Reimer KA, Jennings RB. The 'wavefront phenomenon' of myocardial ischemic cell death. II Transmural progression of necrosis within the framework of ischemic bed size (myocardium at risk) and collateral flow. Lab Invest. 1979;40:633-44.

2. Gersh BJ, Stone GW, White HD, Holmes DR Jr. Pharmacological facilitation of primary percutaneous coronary intervention for acute myocardial infarction: Is the slope of the curve the shape of the future? J Am Med Assoc. 2005;293:979-86.

3. McConaghy JR, Rupal S. Outpatient diagnosis of acute pain in adults. Am Fam Physician 2013;87:177-82.

4. Bruyninckx R, Aertgeerts B, Bruyninckx P, Buntinx F. Signs and symptoms in diagnosing acute myocardial infarction and acute coronary syndrome: A diagnostic meta-analysis. $\mathrm{Br} J$ Gen Pract. 2008;58:105-11.

5. Body R, Carley S, Wibberley C, McDowell G, Ferguson J, Mackway-Jones $K$. The value of symptoms and signs in the emergent diagnosis of acute coronary syndromes. Resuscitation 2010;81:281-6.

6. Rutten FH, Kessels AG, Willems FF, Hoes AW. Electrocardiography in primary care: Is it useful? Int J Cardiol. 2000;74:199-205.

7. Bruins Slot MH, Rutten FH, Van der Heijden GJ, Doevendans PA, Mast EG, Bredero AC, et al. Diagnostic value of a heart-type fatty acid-binding protein (H-FABP) bedside test in suspected acute coronary syndrome in primary care. Int J Cardiol. 2013; 168:1485-9.

8. Nilsson S, Scheike M, Engblom D, Karlsson LG, Mölstad S, Akerlind I, et al. Chest pain and ischaemic heart disease in primary care. Br J Gen Pract. 2003;53:378-82.

9. Bruins Slot $M H$, Rutten FH, Van der Heijden GJ, Geersing GJ, Glatz JF, Hoes AW. Diagnosing acute coronary syndrome in primary care: Comparison of the physicians' risk estimation and a clinical decision rule. Fam Pract. 2011;28:323-8.

10. Newby LK, Jesse RL, Babb JD, Christenson RH, De Fer TM, Diamond GA, et al. ACCF 2012 expert consensus document on 
practical clinical considerations in the interpretation of troponin elevations: A report of the American College of Cardiology Foundation task force on clinical expert consensus documents. J Am Coll Cardiol. 2012;60:2427-63.

11. Thygesen K, Alpert JS, Jaffe AS, Simoons ML, Chaitman BR, White HD: the Writing Group on behalf of the Joint ESC/ACCF/ AHA/WHF Task Force for the Universal Definition of Myocardial Infarction. Third universal definition of myocardial infarction. Circulation 2012;126:2020-35.

12. Nilsson $\mathrm{S}$, Andersson PO, Borgquist L, Grodzinsky E, Janzon M, Kvick $\mathrm{M}$, et al. Point-of-care troponin $\mathrm{T}$ testing in the management of patients with chest pain in the Swedish primary care. Int J Family Med. 2013; doi: 10.1155/2013/532093. Epub 10 January 2013.

13. Glatz JF, Renneberg R. Added value of heart-type fatty acidbinding protein as plasma marker for the early evaluation of suspected acute coronary syndrome. Clin Lipidol. 2014;9: 205-20.

14. Dekker MS, Mosterd A, van 't Hof AW, Hoes AW. Novel biochemical markers in suspected acute coronary syndrome: Systematic review and critical appraisal. Heart 2010;96:1001-10.

15. Glatz JF, van der Vusse GJ, Simoons ML, Kragten JA, van DieijenVisser MP, Hermens WT. Fatty acid-binding protein and the early detection of acute myocardial infarction. Clin Chim Acta. 1998; 272:87-92.

16. Mad P, Domanovits H, Fazelnia C, Stiassny K, Russmuller G, Cseh $A$, et al. Human heart-type fatty-acid-binding protein as a point-of-care-test in the early diagnosis of acute myocardial infarction. QJM 2007;100:203-10.

17. McMahon CG, Lamont JV, Curtin E, McConnell RI, Crockard M, Kurth MJ, et al. Diagnostic accuracy of heart-type fatty acidbinding protein for the early diagnosis of acute myocardial infarction. Am J Emerg Med. 2012;30:267-74.

18. Carroll C, Al Khalaf M, Stevens JW, Leaviss J, Goodacre S, Collinson $\mathrm{PO}$, et al. Heart-type fatty acid binding protein as an early marker for myocardial infarction: Systematic review and meta-analysis. Emerg Med J. 2013;30:280-6.

19. Collinson P, Gaze D, Goodacre S. Comparison of contemporary troponin assays with the novel biomarkers, heart fatty acid binding protein and copeptin, for the early confirmation or exclusion of myocardial infarction in patients presenting to the emergency department with chest pain. Heart 2014;100:140-5.

20. Glatz JF, Mohren R. Plasma reference value of heart-type fatty acid-binding protein, the earliest available plasma biomarker of acute myocardial infarction. Health 2013;5:1206-9.

21. Hamm CW, Bassand JP, Agewall S, Bax J, Boersma E, Bueno $\mathrm{H}$, et al. ESC Guidelines for the management of acute coronary syndromes in patients presenting without persistent ST-segment elevation: The Task Force for the management of acute coronary syndromes (ACS) in patients presenting without persistent STsegment elevation of the European Society of Cardiology (ESC). Eur Heart J. 2011;32:2999-3054.

22. National Clinical Guideline Centre for Acute and Chronic Conditions. Chest pain of recent onset: NICE Guideline. http://www nice org uk/nicemedia/live/12947/47938/47938 pdf (2010 NICE Clinical Guideline 95) (accessed 1 July 2014).

23. Steg PG, James SK, Atar D, Badano LP, Blömstrom-Lundqvist $C$, Borger MA, et al. ESC Guidelines for the management of acute myocardial infarction in patients presenting with ST-segment elevation: The Task Force on the management of ST-segment elevation acute myocardial infarction of the European Society of Cardiology (ESC). Eur Heart J. 2012;33:2569-619.

24. Fox KA, Goodman SG, Klein W, Brieger D, Steg PG, Dabbous O, et al. Management of acute coronary syndromes. Variations in practice and outcome; findings from the global registry of acute coronary events (GRACE). Eur Heart J. 2002;23:1177-89.

25. Hanley JA, McNeil BJ. A method of comparing the areas under receiver operating characteristic curves derived from the same cases. Radiology 1983;148:839-43.

26. Whiting P, Rutjes AW, Reitsma JB, Glas AS, Bossuyt PM, Kleijnen J. Sources of variation and bias in studies of diagnostic accuracy: A systematic review. Ann Intern Med. 2004;140:189-202.

27. Mueller C. Biomarkers and acute coronary syndromes: An update. Eur Heart J. 2014;35:552-6.

28. Willemsen RTA, Buntinx F, Winkens B, Glatz JF, Dinant GJ. The value of signs, symptoms and plasma heart-type fatty acid-binding protein (H-FABP) in evaluating patients presenting with symptoms possibly matching acute coronary syndrome: Background and methods of a diagnostic study in primary care. BMC Fam Pract. 2014;15:203. doi:10.1186/s12875-014-0203-8. 